\title{
EVALUASI COATING MATERIALS UNTUK MELINDUNGI BAKTERI PROBIOTIK PSEUDOALTEROMONAS PISCICIDA SELAMA PROSES MIKROENKAPSULASI DAN PENYIMPANAN
}

\section{EVALUATION OF COATING MATERIALS TO PROTECT PROBIOTIC BACTERIA OF PSEUDOALTEROMONAS PISCICIDA DURING MICROENCAPSULATION AND STORAGE PROCESS}

\author{
D E Ramadhani ${ }^{1}$ dan W Lesmanawati ${ }^{1}$ \\ ${ }^{1}$ Dosen Program Studi Teknologi Produksi dan Manajemen Perikanan Budidaya, Sekolah Vokasi, \\ IPB University \\ email: dianeka06@apps.ipb.ac.id
}

\begin{abstract}
Disease is an obstacle in Pacific white shrimp culture that can cause economic losses. Probiotic bacteria Pseudalteromonas piscicida $1 \mathrm{Ub} \mathrm{Rf}^{\mathrm{R}}$ is able to improve the growth performance and immune responses of Pacific white shrimp and has the potential to be developed into dry products to make it more practical for use in the field. This study aims to obtain the best coating materials that can protect probiotic bacteria during the microencapsulation and storage process. This research was conducted in September-December 2020 at the Laboratory of Microbiology of IPB Sukabumi Campus and South-East Asia Food and Agricultural Science and Technology (SEAFAST). This research consists of 2 Chapters, Chapter 1 to obtain the best coating materials and Chapter 2 to obtain the best results after the microencapsulation process. Coating materials used in this study were whey protein and maltodextrin. The microencapsulation technique used is freeze drying and spray drying. The probiotic bacteria used was $P$. piscicida from Fish Health and Management Laboratory, Department of Aquaculture, FPIK IPB and was marked with rifampicin resistance $\left(1 \mathrm{Ub} \mathrm{Rf}^{\mathrm{R}}\right)$. The research in Chapter 1 consisted of 4 treatments, including $\mathrm{K}$ (without coating material), A (single coating with whey protein), B (single coating with maltodextrin), and $\mathrm{C}$ (double coating with whey protein and maltodextrin). Furthermore, each treatment in Chapter 1 is continued for the microencapsulation process. The results showed that the treatment with double coating and encapsulated by freeze drying was the best probiotic products compared other treatments.
\end{abstract}

Keywords: probiotic, coating materials, microencapsulation, Pseudoalteromonas piscicida

\begin{abstract}
ABSTRAK
Penyakit merupakan kendala dalam budidaya udang vaname yang dapat mengakibatkan kerugian. Bakteri probiotik Pseudoalteromonas piscicda $1 \mathrm{Ub} \mathrm{Rf}^{\mathrm{R}}$ mampu meningkatkan performa pertumbuhan dan respon imun udang vaname dan berpotensi untuk dikembangkan menjadi produk kering agar lebih praktis dalam penggunaan di lapangan. Penelitian ini bertujuan untuk memperoleh coating materials terbaik yang dapat melindungi bakteri probiotik selama proses mikroenkapsulasi dan penyimpanan. Penelitian ini dilakukan pada bulan SeptemberDesember 2020 di Laboratorium Mikrobiologi Kampus IPB Sukabumi dan South-East Asia Food and Agricultural Science and Technology (SEAFAST). Penelitian ini terdiri dari 2 Chapter yaitu: Chapter 1 untuk memperoleh coating material terbaik dan Chapter 2 untuk memperoleh hasil terbaik setelah proses mikroenkapsulasi. Coating material yang digunakan dalam penelitian ini adalah protein whey dan maltodekstrin. Teknik mikroenkapsulasi yang digunakan adalah freeze drying dan spray drying. Bakteri probiotik yang digunakan adalah Pseudoalteromonas piscicida 1Ub yang berasal dari Laboratorium Kesehatan Ikan, Departemen Budidaya Perairan, FPIK IPB dan telah diberi penanda resisten rifampicin $\left(1 \mathrm{Ub} \mathrm{Rf}^{\mathrm{R}}\right)$. Penelitian pada Chapter 1 terdiri dari 4 perlakuan yaitu K (tanpa coating material), A (single coating dengan protein whey), B (single coating dengan maltodekstrin), dan C (double coating dengan protein whey dan maltodekstrin). Selanjutnya masing-masing perlakuan pada Chapter 1 dilanjutkan untuk proses mikroenkapsulasi. Hasil penelitian menunjukkan bahwa perlakuan dengan double coating dan dienkapsulasi dengan freeze drying menghasilkan produk probiotik yang terbaik dibandingkan perlakuan lainnya.
\end{abstract}

Kata kunci: probiotik, coating materials, mikroenkapsulasi, Pseudoalteromonas piscicida

Dian Eka Ramadhani, Wida Lesmanawati. 2021. Evaluasi Coating Materials untuk Melindungi Bakteri Probiotik Pseudoalteromonas piscicida Selama Proses Mikroenkapsulasi dan Penyimpanan. Jurnal Mina Sains, 7 (2) : 52-61. 


\section{PENDAHULUAN}

Penyakit merupakan salah satu kendala utama dalam kegiatan budidaya udang karena dapat mengakibatkan kerugian ekonomi yang cukup besar bagi para petambak udang. Salah satu alternatif untuk menanggulangi penyakit pada budidaya udang yaitu probiotik. Probiotik merupakan mikroba hidup yang bila diberikan dalam jumlah yang cukup dapat memberikan pengaruh menguntungkan bagi kesehatan inang dan dapat meningkatkan keseimbangan mikroba dalam saluran pencernaan, efisiensi pakan, dan kualitas lingkungan (Nayak 2010). Beberapa penelitian melaporkan bahwa probiotik mampu meningkatkan kelangsungan hidup, performa pertumbuhan dan respons imun pada udang vaname (Hamsah et al. 2017; 2019; Zokaeifar et al. 2014; Nimrat et al. 2012). Probiotik yang digunakan dalam penelitian ini adalah bakteri probiotik Pseudoalteromonas piscicida 1Ub yang telah teruji kemampuannya dalam menghambat pertumbuhan bakteri patogen Vibrio harveyi dan secara signifikan mampu meningkatkan kelangsungan hidup serta performa pertumbuhan pada larva udang windu (Widanarni et al. 2009).

Hasil penelitian Hamsah et al. (2017) menunjukkan bahwa kultur segar bakteri probiotik $P$. alteromonas $1 \mathrm{Ub}$ mampu meningkatkan performa pertumbuhan larva udang vaname. Namun, penggunaan kultur segar bakteri probiotik memiliki kelemahan diantaranya daya simpan yang terbatas dan tidak praktis dalam penggunaannya. Berdasarkan hasil riset tersebut bakteri probiotik ini berpotensi untuk dikembangkan menjadi produk kering. Mikroenkapsulasi merupakan teknologi yang berfungsi untuk mempertahankan viabilitas bakteri dalam waktu yang lama (Martin et al. 2015).

Teknologi ini banyak dimanfaatkan dalam berbagai bidang farmasi, pangan, dan akuakultur. Proses mikroenkapsulasi bakteri probiotik sendiri memerlukan berbagai persiapan, diantaranya penyiapan bahan penyalut atau coating materials. Pemilihan coating materials tergantung pada bahan aktif yang akan dienkapsulasi, kemampuan untuk melindungi materi inti dengan baik, dan kemampuan release di air maupun di saluran pencernaan inang. Beberapa coating materials yang umumnya digunakan diantaranya, maltodekstrin, cyclodextrin, selulosa, lipid (wax, paraffin, diacylglycerols), gum (agar, carrageenan) dan protein (gluten, casein, dan gelatin).

Penelitian ini menggunakan coating material protein whey dan maltodekstrin. Protein whey merupakan protein globular yang banyak ditemukan dalam fraksi whey susu seperti $\beta$-laktoglobulin ( $\beta$-LG), $\alpha$ laktobumin ( $\alpha$-LA), dan bovine serum albumin (BSA) (Maqsood et al. 2019). Protein whey banyak digunakan sebagai bahan fungsional dalam berbagai aplikasi seperti industri makanan, terutama sebagai pengemulsi, pembentuk gel, bahan susu formula, bahan penyalut untuk enkapsulasi, dan sebagainya (Krolczyk et al. 2016). Protein whey ini memiliki kemampuan untuk berinteraksi dengan berbagai molekul aktif dan memiliki kemampuan untuk melindungi molekul aktif (Martin et al. 2015). Doherty et al. (2011) melaporkan bahwa protein whey sebagai coating materal yang dapat melindungi probiotik selama inkubasi 3 jam secara in-vitro. Maltodekstrin merupakan coating material polysaccharides-based yang memiliki kemampuan melindungi molekul aktif, meningkatkan viabilitas sel selama proses mikroenkapsulasi dan selama penyimpanan bakteri kering (Semyonov et al. 2011). Kedua bahan ini adalah coating material yang mudah didapatkan, harganya murah, mampu melindungi bakteri probiotik selama proses enkapsulasi dan feasible secara ekonomi. Oleh karena itu, penelitian ini bertujuan untuk memperoleh coating 
material terbaik yang dapat melindungi bakteri probiotik selama proses mikroenkapsulasi.

\section{BAHAN DAN METODE}

\section{Waktu dan Tempat Penelitian}

Penelitian ini dilakukan pada bulan September-Desember 2020 di Laboratorium Mikrobiologi Kampus IPB Sukabumi dan South-East Asia Food and Agricultural Science and Technology (SEAFAST) IPB.

\section{Alat dan Bahan}

Alat yang digunakan dalam penelitian antara lain mikropipet 100-1000 $\mu \mathrm{L}$, mikropipet 10-100 $\mu \mathrm{L}$, ependorf 1.5 mL, mikrotip $200 \mu \mathrm{L}$, mikrotip $1.000 \mu \mathrm{L}$, erlenmeyer $100 \mathrm{~mL}, 250 \mathrm{~mL}$, dan $500 \mathrm{~mL}$, shaker, spray drying menggunakan MINIBUCHI spray dryer pada suhu inlet 110 - $113{ }^{\circ} \mathrm{C}$ dan suhu outlet $80{ }^{\circ} \mathrm{C}$. Sedangkan freeze drying menggunakan LABCONCO freeze dryer pada suhu -50 ${ }^{\circ} \mathrm{C}$, freeze dryer, spray dryer, sentrifuse, cawan petri, tabung reaksi, batang pengaduk, batang penyebar, jarum ose, kompor listrik, korek api, dan panci. Bahan yang digunakan antara lain, sea water complete-agar; $0.5 \mathrm{~g}$ bactopeptone, $0.1 \mathrm{~g}$ yeast extract, $0.3 \mathrm{~mL}$ glycerol, $1.5 \mathrm{~g}$ bacto agar, $75 \mathrm{~mL}$ air laut, $25 \mathrm{~mL}$ akuades, rifampisin, phosphate buffer saline (PBS, $0.8 \mathrm{~g} \mathrm{NaCl}, 0.02 \mathrm{~g} \quad \mathrm{KH}_{2} \mathrm{PO}_{4}, 0.05 \mathrm{~g}$ $\mathrm{Na}_{2} \mathrm{HPO}_{4}, 0.02 \mathrm{KCl}, 100 \mathrm{~mL}$ akuades), susu sapi, pill rennet, maltodekstrin, dan $\mathrm{CaCl}_{2}$ $40 \%(\mathrm{~m} / \mathrm{v})$.

\section{Desain Penelitian}

Penelitian ini terdiri dari 2 Chapter yaitu : Chapter 1 untuk mendapatkan coating materials terbaik dan Chapter 2 untuk mendapatkan teknik mikroenkapsulasi terbaik. Chapter 1 terdiri dari 4 perlakuan diantaranya K (tanpa coating material, hanya menggunakan
PBS), A (single coating dengan protein whey), $\mathrm{B}$ (single coating dengan maltodekstrin), dan C (double coating dengan protein whey dan maltodekstrin). Sedangkan Chapter 2 terdiri dari 8 perlakuan yaitu K (tanpa coating material dan dilakukan spray drying), A (single coating dengan protein whey dan dilakukan spray drying), B (single coating dengan maltodekstrin dan dilakukan spray drying), $\mathrm{C}$ (double coating dengan protein whey dan maltodekstrin, serta dilakukan spray drying), D (tanpa coating material dan dilakukan freeze drying), $\mathrm{E}$ (single coating dengan protein whey dan dilakukan freeze drying), $\mathrm{F}$ (double coating dengan protein whey dan dilakukan freeze drying), dan $\mathrm{G}$ (double coating dengan maltodekstrin dan dilakukan freeze drying).

\section{Penyiapan Probiotik}

Probiotik yang digunakan adalah bakteri probiotik Pseudoalteromonas piscicida $1 \mathrm{Ub}$ hasil isolasi dari nauplii udang vaname (Widanarni et al. 2009) dan telah dibuat resisten terhadap antibiotik rifampisin $50 \mu \mathrm{g} \mathrm{mL}^{-1}\left(1 \mathrm{Ub} \mathrm{Rf}^{\mathrm{R}}\right)$ sebagai penanda. Bakteri probiotik $1 \mathrm{Ub} \mathrm{Rf}^{\mathrm{R}}$ ditumbuhkan dalam media SWC-agar (sea water complete-agar; $0.5 \mathrm{~g}$ bactopeptone, $0.1 \mathrm{~g}$ yeast extract, $0.3 \mathrm{~mL}$ glycerol, $1.5 \mathrm{~g}$ bacto agar, $75 \mathrm{~mL}$ air laut, $25 \mathrm{~mL}$ akuades) dan diinkubasi pada suhu $29{ }^{\circ} \mathrm{C}$ dalam inkubator selama 24 jam. Kemudian bakteri probiotik $1 \mathrm{Ub} \mathrm{Rf}^{\mathrm{R}}$ dikultur dalam $50 \mathrm{~mL}$ media SWC-cair dan diinkubasi di shaker pada suhu ruang dengan kecepatan $140 \mathrm{rpm}$ selama 18 jam. Setelah itu kultur bakteri probiotik dilanjutkan dengan metode upscaling (1:10), dimana hasil kultur bakteri probiotik pada media $50 \mathrm{~mL}$ SWCcair dituang secara steril dalam media 500 $\mathrm{mL}$ SWC-cair dan diinkubasi di shaker pada suhu ruang $\left(25^{\circ} \mathrm{C}\right)$ dengan kecepatan $140 \mathrm{rpm}$ selama 18 jam. Selanjutnya bakteri probiotik $1 \mathrm{Ub} \quad \mathrm{Rf}^{\mathrm{R}}$ disentrifugasi menggunakan sentrifuse kecepatan 10.000 
rpm selama 10 menit. Selanjutnya pellet bakteri tersebut dicuci menggunakan 500 $\mathrm{mL}$ larutan PBS. Bakteri probiotik siap digunakan untuk proses penyalutan dan mikroenkapsulasi.

\section{Penyiapan Coating Materials}

Coating materials atau bahan
penyalut yang digunakan adalah maltodekstrin 10\% (100 g maltodekstrin; 1 $\mathrm{L}$ akuades steril) dan protein whey. Protein whey didapatkan dari proses koagulasi enzimatik dari susu pasteurisasi (De CastroCislaghi et al. 2012) dengan penambahan pill rennet $0.05 \mathrm{~g} \mathrm{~L}^{-1}$ (Enzimaks, IIEC Iran) dan $\mathrm{CaCl}_{2} 40 \%(\mathrm{~m} / \mathrm{v})\left(0.04 \mathrm{~mL} \mathrm{~L}^{-1}\right)$. Susu sapi segar dimasak pada suhu $60^{\circ} \mathrm{C}$ selama 15 menit dan diaduk-aduk. Setelah itu didiamkan hingga suhunya mencapai sekitar $20-30^{\circ} \mathrm{C}$, lalu ditambahkan pill rennet dan $\mathrm{CaCl}_{2}$ yang sebelumnya telah dilarutkan dalam 5-10 mL akuades steril. Selanjutnya diaduk hingga merata dan didiamkan pada suhu ruang hingga terbentuk gumpalan yang terpisah dari cairan di bawahnya. Setelah itu disaring menggunakan kain mori warna putih dan cairan yang terbentuk merupakan protein whey yang siap digunakan sebagai coating material. Protein whey dapat langsung digunakan atau dapat disimpan dalam suhu $4{ }^{\circ} \mathrm{C}$ (suhu kulkas).

\section{Proses Mikroenkapsulasi}

Teknik mikroenkapsulasi yang digunakan adalah spray drying dan freeze drying. Tahap pertama yaitu pencampuran bakteri probiotik $1 \mathrm{Ub} \mathrm{Rf}^{\mathrm{R}}$, protein whey dan maltodekstrin 1:1:0.1 (v/v/v). Tahap kedua (mikroenkapsulasi) yaitu spray drying menggunakan MINIBUCHI spray dryer pada suhu inlet $110-113^{\circ} \mathrm{C}$ dan suhu outlet $80{ }^{\circ} \mathrm{C}$. Sedangkan freeze drying menggunakan LABCONCO freeze dryer pada suhu $\quad-50 \quad{ }^{\circ} \mathrm{C}$. Hasil enkapsulasi kemudian disimpan dalam wadah kemasan dan dapat digunakan langsung maupun disimpan pada lemari pendingin pada suhu $-20^{\circ} \mathrm{C}$.

\section{Parameter Pengamatan}

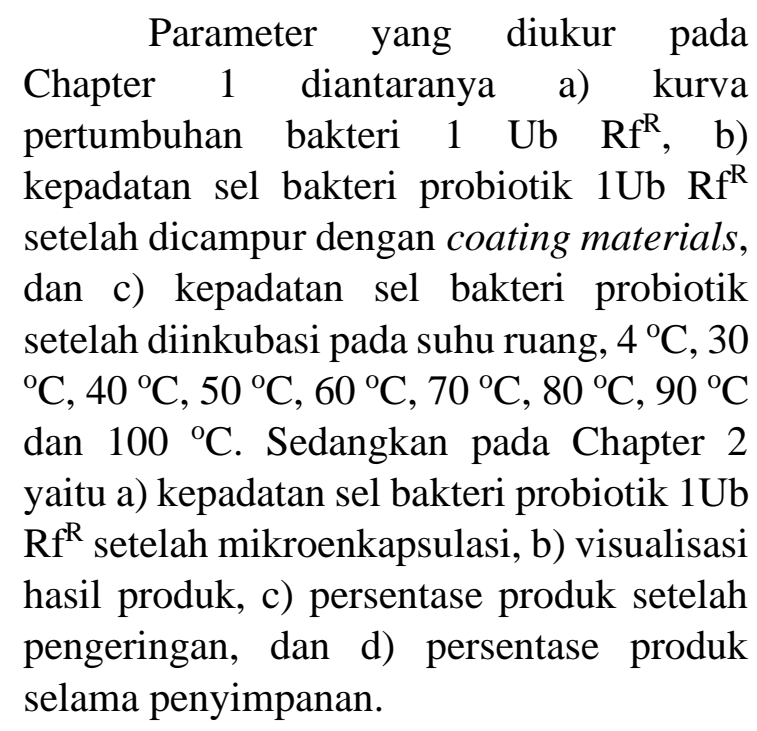

\section{Analisis Data}

Data penelitian ditabulasikan dalam Microsoft Excel 2016 dan analisis data dilakukan menggunakan SPSS 24.0. Parameter pada Chapter 1 dan 2 dianalisis secara deskriptif menggunakan tabel dan grafik.

\section{HASIL DAN PEMBAHASAN}

\section{Chapter 1. Coating Materials}

\section{Kepadatan bakteri probiotik $1 \mathrm{Ub} \mathbf{R f}^{\mathbf{R}}$ setelah diberikan coating materials}

Berikut ini adalah Gambar 1 yang menunjukkan kepadatan bakteri probiotik $1 \mathrm{Ub} \mathrm{Rf}^{\mathrm{R}}$ setelah diberikan coating materials. Hasil menunjukkan bahwa perlakuan B $\left(2.00 \times 10^{9} \mathrm{CFU} / \mathrm{mL}\right)$ dan $\mathrm{C}$ $\left(1.96 \times 10^{9} \mathrm{CFU} / \mathrm{mL}\right)$ lebih tinggi dibandingkan dengan perlakuan $\mathrm{K}(1.40 \mathrm{x}$ $\left.10^{9} \mathrm{CFU} / \mathrm{mL}\right)$ dan A ( $\left.8.20 \times 10^{8} \mathrm{CFU} / \mathrm{mL}\right)$. 
Tabel 1. Kepadatan bakteri probiotik $1 \mathrm{Ub}$ $\mathrm{Rf}^{\mathrm{R}}$ setelah diberikan coating material

\begin{tabular}{cc}
\hline Perlakuan & $\begin{array}{c}\text { Kepadatan bakteri probiotik } \\
\text { 1Ub Rf }^{\mathrm{R}} \text { setelah dicoating } \\
(\mathrm{CFU} / \mathrm{mL})\end{array}$ \\
\hline $\mathrm{K}$ & $1.40 \times 10^{9}$ \\
$\mathrm{~A}$ & $8.20 \times 10^{8}$ \\
$\mathrm{~B}$ & $2.00 \times 10^{9}$ \\
$\mathrm{C}$ & $1.96 \times 10^{9}$ \\
\hline
\end{tabular}

Keterangan: A (single coating dengan protein whey), B (single coating dengan maltodekstrin), dan $\mathrm{C}$ (double coating dengan protein whey dan maltodekstrin)

\section{Kepadatan bakteri probiotik $1 \mathrm{Ub} \mathbf{R f}^{\mathrm{R}}$ setelah diinkubasi pada berbagai suhu}

Berikut ini adalah Tabel 2 yang menunjukkan kepadatan bakteri probiotik $1 \mathrm{Ub} \mathrm{Rf}^{\mathrm{R}}$ setelah diinkubasi pada berbagai suhu yakni suhu ruang $\left(25-29^{\circ} \mathrm{C}\right), 4^{\circ} \mathrm{C}, 30$ ${ }^{\circ} \mathrm{C}, 40{ }^{\circ} \mathrm{C}, 50{ }^{\circ} \mathrm{C}, 60{ }^{\circ} \mathrm{C}, 70{ }^{\circ} \mathrm{C}, 80{ }^{\circ} \mathrm{C}, 90{ }^{\circ} \mathrm{C}$. dan $100{ }^{\circ} \mathrm{C}$. Hasil menunjukkan bahwa perlakuan $\mathrm{B}$ dan $\mathrm{C}$ menghasilkan viabilitas bakteri lebih tinggi saat diinkubasi dalam suhu ruang, $4{ }^{\circ} \mathrm{C}, \quad 30{ }^{\circ} \mathrm{C}$, dan $40{ }^{\circ} \mathrm{C}$, dibandingkan pada perlakuan $\mathrm{K}$ dan $\mathrm{A}$. Pada saat diinkubasi pada suhu $50^{\circ} \mathrm{C}-100^{\circ} \mathrm{C}$ tidak ada bakteri yang tumbuh.

Tabel 2 Kepadatan bakteri probiotik $1 \mathrm{Ub}$ $\mathrm{Rf}^{\mathrm{R}}$ setelah diinkubasi pada berbagai suhu

\begin{tabular}{|c|c|c|c|c|c|}
\hline \multirow{2}{*}{ Perlakuan } & \multicolumn{5}{|c|}{$\begin{array}{l}\text { Kepadatan bakteri probiotik } 1 \mathrm{Ub} \mathrm{Rf}^{\mathrm{R}} \text { setelah } \\
\text { diinkubasi di berbagai suhu }(\mathrm{CFU} / \mathrm{mL})\end{array}$} \\
\hline & $4^{\circ} \mathrm{C}$ & $25^{\circ} \mathrm{C}$ & $30^{\circ} \mathrm{C}$ & $40^{\circ} \mathrm{C}$ & $\begin{array}{r}50- \\
100^{\circ} \mathrm{C}\end{array}$ \\
\hline $\mathrm{K}$ & $\begin{array}{l}1.30 \\
\times 10^{9}\end{array}$ & $\begin{array}{r}1.40 \\
\times 10^{9}\end{array}$ & $\begin{array}{c}1.20 \\
\mathrm{x} 10^{9}\end{array}$ & $\begin{array}{c}1.10 \mathrm{x} \\
10^{9}\end{array}$ & TB \\
\hline A & $\begin{array}{c}8.12 \mathrm{x} \\
10^{8}\end{array}$ & $\begin{array}{r}8.20 \\
\times 10^{9}\end{array}$ & $\begin{array}{r}7.80 \\
\times 10^{8}\end{array}$ & $\begin{array}{c}7.20 x \\
108\end{array}$ & TB \\
\hline B & $\begin{array}{c}1.98 \times \\
10^{9}\end{array}$ & $\begin{array}{r}2.00 \\
\times 10^{9}\end{array}$ & $\begin{array}{l}1.86 \\
\mathrm{x} 10^{8}\end{array}$ & $\begin{array}{c}1.86 \mathrm{x} \\
10^{9}\end{array}$ & TB \\
\hline $\mathrm{C}$ & $\begin{array}{c}1.83 \mathrm{x} \\
10^{9}\end{array}$ & $\begin{array}{r}1.96 \\
\times 10^{9} \\
\end{array}$ & $\begin{array}{c}1.76 \\
10^{8}\end{array}$ & $\begin{array}{c}1.76 \mathrm{x} \\
10^{9}\end{array}$ & TB \\
\hline
\end{tabular}

Keterangan: A (single coating dengan protein whey), B (single coating dengan maltodekstrin), dan $\mathrm{C}$ (double coating dengan protein whey dan maltodekstrin), TB (tidak tumbuh).

Chapter 2. Teknik Mikroenkapsulasi Kepadatan bakteri probiotik $1 \mathrm{Ub} \mathbf{R f}^{\mathrm{R}}$ setelah dienkapsulasi menggunakan metode spray drying dan freeze drying
Berikut ini adalah Tabel 3 yang menunjukkan kepadatan bakteri probiotik $1 \mathrm{Ub} \quad \mathrm{Rf}^{\mathrm{R}}$ setelah dienkapsulasi menggunakan metode spray drying dan freeze drying. Hasil menunjukkan bahwa perlakuan $G$ menghasilkan viabilitas bakteri tertinggi yaitu $8.60 \times 10^{5} \mathrm{CFU} / \mathrm{mL}$ dibandingkan perlakuan lainnya. Selanjutnya hasil pengamatan secara visual terhadap produk bakteri probiotik $1 \mathrm{Ub} \mathrm{Rf}^{\mathrm{R}}$ yang telah dienkapsulasi dan disimpan selama 1 bulan. Hasil menunjukkan bahwa coating material yang mengandung maltodekstrin dan dienkapsulasi dengan spray drying memberikan hasil warna serbuk putih, kering, serbuk yang dihasilkan lebih kecil dan tidak lengket. Hasil coating material dari protein whey dan dienkapsulasi dengan freeze drying menghasilkan produk berwarna krem kekuningan, kering, dan tidak lengket.

Tabel 3. Kepadatan bakteri probiotik $1 \mathrm{Ub}$ $\mathrm{Rf}^{\mathrm{R}}$ setelah dienkapsulasi dan hasil visualisasi produk enkapsulasi

\begin{tabular}{|c|c|c|}
\hline Perlakuan & $\begin{array}{l}\text { Kepadatan } \\
\text { bakteri } \\
\text { probiotik 1Ub } \\
\text { Rf }^{\mathrm{R}} \text { setelah } \\
\text { dienkapsulasi }\end{array}$ & $\begin{array}{c}\text { Hasil } \\
\text { visualisasi } \\
\text { produk }\end{array}$ \\
\hline $\mathrm{K}$ & 0 & putih kering \\
\hline A & 0 & putih kering \\
\hline B & 0 & putih kering \\
\hline $\mathrm{C}$ & 0 & putih kering \\
\hline $\mathrm{D}$ & 0 & $\begin{array}{c}\text { krem dan } \\
\text { sedikit lenget }\end{array}$ \\
\hline $\mathrm{E}$ & $1.16 \times 10^{4}$ & krem, kering \\
\hline $\mathrm{F}$ & $5.80 \times 10^{4}$ & $\begin{array}{l}\text { krem agak } \\
\text { bening dan } \\
\text { kering }\end{array}$ \\
\hline G & $8.60 \times 10^{5}$ & $\begin{array}{c}\text { krem } \\
\text { kekuningan } \\
\text { dan kering }\end{array}$ \\
\hline
\end{tabular}

Keterangan: K (tanpa coating material dan dilakukan spray drying), A (single coating dengan protein whey dan dilakukan spray drying), B (single coating dengan maltodekstrin dan dilakukan spray drying), C (double coating dengan protein whey dan maltodekstrin, serta dilakukan spray drying), D (tanpa coating material dan dilakukan freeze drying), E (single coating dengan protein whey dan dilakukan freeze drying), F (double coating dengan protein whey dan dilakukan freeze drying), dan G 
(double coating dengan maltodekstrin dan dilakukan freeze drying).

Berikut ini adalah Gambar 1 yang menunjukkan persentase produk bakteri probiotik $1 \mathrm{Ub} \mathrm{Rf}^{\mathrm{R}}$ setelah penyimpanan selama 1 bulan. Hasil menunjukkan bahwa perlakuan $\mathrm{G}$ menghasilkan persentase tertinggi (99.40\%) dibandingkan perlakuan lainnya.

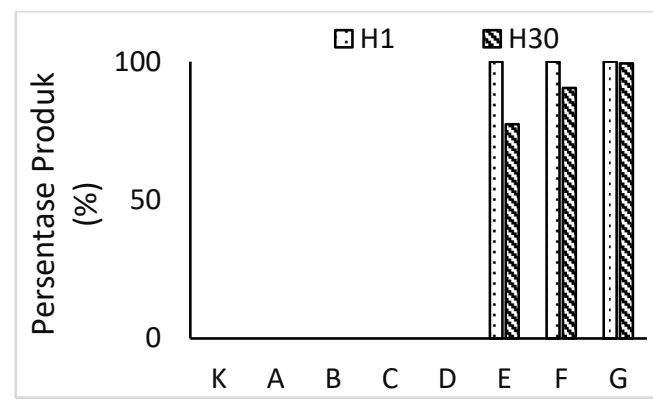

Gambar 1. Persentase produk bakteri probiotik $1 \mathrm{Ub} \mathrm{Rf}^{\mathrm{R}}$ setelah penyimpanan selama 1 bulan. K (tanpa coating material dan dilakukan spray drying), A (single coating dengan protein whey dan dilakukan spray drying), B (single coating dengan maltodekstrin dan dilakukan spray drying), C (double coating dengan protein whey dan maltodekstrin, serta dilakukan spray drying), D (tanpa coating material dan dilakukan freeze drying), E (single coating dengan protein whey dan dilakukan freeze drying), $\mathrm{F}$ (double coating dengan protein whey dan dilakukan freeze drying), dan G (double coating dengan maltodekstrin dan dilakukan freeze drying).

\section{Pembahasan}

Hasil penelitian menunjukkan bahwa bakteri probiotik yang diberikan coating material B (single coating dengan maltodekstrin) memiliki viabilitas lebih tinggi yaitu sekitar $2.00 \times 10^{9} \mathrm{CFU} / \mathrm{mL}$, kemudian pada perlakuan $\mathrm{C}$ (double coating dengan protein whey dan maltodekstrin) juga menunjukkan viabilitas yang tinggi yaitu 1.96 x $10^{9} \mathrm{CFU} / \mathrm{mL}$ dibandingkan dengan perlakuan lainnya. Hasil tersebut menunjukkan bahwa adanya penambahan coating material tidak membuat viabilitas bakteri menjadi turun dan lebih stabil. Selanjutnya bakteri probiotik $1 \mathrm{Ub} \mathrm{Rf}^{\mathrm{R}}$ diujikan dengan beberapa uji dengan tujuan untuk melihat pengaruhnya terhadap suhu dingin dan panas. Hasil menunjukkan bahwa bakteri probiotik $1 \mathrm{Ub} \mathrm{Rf}^{\mathrm{R}}$ hanya dapat bertahan pada suhu $4^{\circ} \mathrm{C}-40^{\circ} \mathrm{C}$ dan perlakuan yang menghasilkan viabilitas tinggi pada saat diinkubasi pada suhu tersebut yaitu perlakuan $\mathrm{B}$ dan $\mathrm{C}$ dibandingkan dengan perlakuan $\mathrm{K}$ dan $\mathrm{A}$. Pada saat suhu dinaikkan menjadi $50^{\circ} \mathrm{C}-100^{\circ} \mathrm{C}$, bakteri probiotik $1 \mathrm{Ub} \mathrm{Rf}^{\mathrm{R}}$ tidak ada yang tumbuh.

Coating material memberikan perlindungan terhadap mikroorganisme melalui kontrol mekanisme respons stress terhadap lingkungan lambung yang melibatkan kelembaban, migrasi zat terlarut, pertukaran gas, laju reaksi oksidatif dan sebagainya (Peach-Canul et al. 2020). Coating material maltodekstrin merupakan makromolekul yang tidak membawa muatan formal (polisakarida non-ionik). Maltodekstrin sering digunakan sebagai coating material untuk mikroenkapsulasi probiotik (Peach-Canul et al. 2020; Shori 2017). Maltodekstrin memiliki beberapa sifat yang cocok untuk mikroenkapsulasi diantaranya memiliki kelarutan yang baik, pembentukan film yang baik, kontrol kelembaban, mudah dicerna, memudahkan pada tahap pengeringan semprot, dan sebagainya (Peach-Canul et al. 2020). Dalam hal ini, maltodekstrin memiliki efek secara positif dapat melindungi dan mempertahankan viabilitas bakteri probiotik $1 \mathrm{Ub} \mathrm{Rf}^{\mathrm{R}}$ lebih baik dibandingkan pemberian protein whey secara tunggal.

Perlakuan double coating antara maltodekstrin dan protein whey juga dapat melindungi bakteri probiotik dan menghasilkan viabilitas yang lebih tinggi dibandingkan dengan single coating protein whey dan kontrol pada suhu $4^{\circ} \mathrm{C}-40^{\circ} \mathrm{C}$. Hasil ini selanjutnya akan diteruskan pada tahap mikroenkapsulasi dan sebagai dasar untuk pemilihan metode mikroenkapsulasi yang tepat. Protein merupakan bahan yang baik untuk mikroenkapsulasi probiotik dan sering digunakan dalam campurang dengan coating material lainnya (Dolly et al. 2011; Gomez et al. 2016; Doherty et al. 2011; Zou 
et al. 2012). Protein telah banyak digunakan sebagai coating material karena memiliki sifat sebagai penghambat yang baik terhadap permeabilitas $\mathrm{O}_{2}$ dan $\mathrm{CO}_{2}$. Protein yang digunakan sebagai coating material dapat dikategorikan menurut sifatnya yaitu protein nabati dan hewani. Contoh protein dari sumber hewani yaitu gelatin, kasein, konsentrat protein whey (WCP, isolate protein whey (WPI), putih telur dan kaseinat. Protein susu yang digunakan sebagai coating material tersedia dalam bentuk asli dan olahan. Protein whey didefinisikan sebagai protein yang tetap ada dalam larutan setelah penghilangan kasein dari susu (Mulvihill et al. 1987; Augustin et al. 2014). Protein whey terdiri dari lactoglobulin $(\beta-\mathrm{LG})$, alpalaktalbumin $(\alpha-$ LA), immuno-globulin, dan serum albumin. Pada $\mathrm{pH} 4.6$ protein larut. Protein whey tersedia secara komersial sebagai konsentrat (WCP) dan isolate (WPI) yang masing-masing mengandung 35-85\% dan $>95 \%$ protein. Protein -LG dalam susu sapi mewakili jumlah tertinggi dari komposisi protein whey yaitu 50-60\%.

Bakteri probiotik $1 \mathrm{Ub} \mathrm{Rf}^{\mathrm{R}}$ tidak dapat bertahan pada saat suhu dinaikkan hingga $50-100{ }^{\circ} \mathrm{C}$. Hal tersebut kemungkinan karena strain dari bakteri probiotik tidak tahan terhadap suhu panas. Perlindungan dari coating material sendiri belum bisa melindungi bakteri tersebut dalam kondisi suhu panas. Bakteri probiotik Pseudoalteromonas piscicida $1 \mathrm{Ub} \mathrm{Rf}^{\mathrm{R}}$ merupakan bakteri Gram negatif yang banyak ditemukan di air laut dan umumnya tumbuh baik pada suhu sekitar $25^{\circ} \mathrm{C}$ (Richard et al. 2017). Bakteri ini sebelumnya belum pernah dilakukan mikroenkapsulasi dan belum pernah diuji coba dengan beberapa coating material. Beberapa penelitian melaporkan bahwa mikroenkapsulasi sering digunakan untuk melindungi probotik dari lingkungan ekstrim (McClements et al. 2012; Monnard et al. 1997).
Mikroenkapsulasi merupakan salah satu metode yang paling efisien untuk mempertahankan viabilitas sel mikroorganisme selama pengeringan, penyimpanan dan mengubahnya dalam bentuk bubuk sehingga lebih mudah unuk digunakan (Mortazavian et al. 2007). Efisiensi perlindungan yang diberikan oleh mikroenkapsulasi tergantung pada metode mikroenkapsulasi, strain mikroorganisme probiotik, coating material dan sebagainya (Peach-Canul et al. 2020; Shori 2017). Mikroenkapsulasi yang biasa digunakan diantaranya spray drying, freeze drying, rennet-gelled protein encapsulation, fluid bed, two-step drying, spray-freeze drying, dan sebagainya. Spray drying merupakan metode mikroenkasulasi yang paling umum digunakan dalam industri makanan karena ekonomis dan fleksibel (Martin et al. 2015). Hasil penelitian menunjukkan bahwa bakteri probiotik pada perlakuan yang dienkapsulasi dengan spray drying tidak ada bakteri probiotik $1 \mathrm{Ub} \mathrm{Rf}^{\mathrm{R}}$ yang tumbuh. Hal ini dapat disebabkan karena suhu tinggi yang digunakan dalam proses kemungkinan tidak cocok untuk bakteri probiotik yang tidak tahan panas. Pada saat proses pengerinan, suhu outlet sekitar $80-90^{\circ} \mathrm{C}$ dan ini akan mematikan bagi strain bakteri probiotik tersebut (Peach-Canul et al. 2020). Faktor lain yang mempengaruhi viabilitas probiotik spray drying adalah jenis strain dan toleransinya terhadap kondisi stress, suhu, dan waktu pengeringan (Martin et al. 2015).

Hasil enkapsulasi pada freeze drying dengan single coating maltodekstrin, single coating protein whey dan double coating (maltodekstrin dan protein whey) menunjukkan bahwa bakteri probiotik $1 \mathrm{Ub}$ $\mathrm{Rf}^{\mathrm{R}}$ dapat tumbuh mulai dari $1.16 \times 10^{4}-$ $8.60 \times 10^{5} \mathrm{CFU} / \mathrm{mL}$. Hasil tertinggi didapatkan pada perlakuan double coating yang menghasilkan viabilitas bakteri yaitu $8.60 \times 10^{5} \mathrm{CFU} / \mathrm{mL}$. Hal ini menunjukkan bahwa bakteri probiotik $1 \mathrm{Ub} \mathrm{Rf}^{\mathrm{R}}$ dapat 
dikeringkan menggunakan freeze drying dan kombinasi coating material yang tepat adalah maltodekstrin dan protein whey. Selain itu, suhu pada mesin freeze drying juga mendukung untuk pembuatan bakteri probiotik menjadi kering. Pada tahap sebelumnya juga telah diujikan bahwa bakteri ini dapat bertahan pada suhu dingin sedangkan pada suhu panas mengalami kematian sel. Selain itu, persentase produk yang dihasilkan lebih tinggi dan sebanyak 99.40\% bakteri probiotik $1 \mathrm{Ub} \mathrm{Rf}^{\mathrm{R}}$ dapat bertahan selama 1 bulan. Menurut Amezquita et al. 2016 prinsip freeze drying yaitu sublimasi yang terjadi ketika tekanan uap air dan suhu es lebih rendah dari titik $0.61 \mathrm{kPa}(4.58 \mathrm{mmHg}$ atau $0.006 \mathrm{~atm})$ dan $273.16 \mathrm{~K}\left(0.01^{\circ} \mathrm{C}\right)$. Suhu pada freeze dryer dapat mencapai antara $\leq-80{ }^{\circ} \mathrm{C}-\leq-56{ }^{\circ} \mathrm{C}$. Menurut Wang et al. (2004) pengeringan menggunakan freeze drying lebih ringan dibandingkan dengan pengeringan dengan spray drying dan viabilitas bakteri probiotik lebih tinggi. Freeze drying telah banyak digunakan untuk memproduksi probiotik kering dalam dekade terakhir. Prosesnya didasarkan pada sublimasi dan terdapat tiga fase diantaranya, pembekuan, pengeringan primer dan pengeringan skunder (Santivarangkna et al. 2007). Berbagai coating material yang dapat ditambahkan sebelum freeze drying dapat berupa protein whey, glukosa, maltodekstrin, trehalose dan lain-lain (Basholli-Salihu et al. 2014). Peneliti lainnya melaporkan bahwa bahwa mikroenkapsulasi dengan spray freeze drying Lactobacillus paracasei menggunakan maltodekstrin dan trehalose sebagai coating materials yang secara signifikan meningkatkan kelangsungan hidup dan viabilitas probiotik (Semyonov et al. 2010).

Hasil visualisasi menunjuk-kan bahwa karakteristik produk yang diberikan coating material malto-dekstrin cenderung berwarna putih, sedangkan produk yang diberikan coating material protein whey cenderung berwarna krem kekuningan. Kombinasi antara maltodekstrin dan protein whey menghasilkan karakteristik warna putih sedikit kekuningan. Karakteristik hasil enkapsulasi dengan spray drying, produk yang dihasilkan umumnya berwarna putih dan halus, sedangkan hasil enkapsulasi dengan freeze drying produk yang dihasilkan umumnya berwarna kremkeku-ningan. Setelah penyimpanan selama 1 bulan, perlakuan double coating dengan maltodekstrin dan dilakukan freeze drying) menghasilkan persen-tase produk tertinggi 99.40\% yang artinya bakteri probiotik memiliki kepadatan sel yang tetap selama periode penyimpanan tersebut.

\section{KESIMPULAN DAN REKOMENDASI}

\section{Kesimpulan}

Coating material terbaik yang didapatkan adalah double coating antara maltodekstrin dan protein whey. Metode terbaik yang dapat digunakan untuk membuat produk probiotik $1 \mathrm{Ub} \mathrm{Rf}^{\mathrm{R}}$ kering yaitu freeze drying dengan double coating material maltodekstrin dan protein whey. Kombinasi coating material dan metode mikroenkapsulasi terbaik dalam penelitian ini menghasilkan produk probiotik lebih baik dibandingan dengan perlakuan lainnya.

\section{Rekomendasi}

Penelitian selanjutnya diper-lukan kombinasi coating material untuk mendapatkan produk probiotik $1 \mathrm{UB} \mathrm{Rf}^{\mathrm{R}}$ dengan viabilitas lebih tinggi daripada penelitian ini.

\section{DAFTAR PUSTAKA}

Augustin MA, Oliver CM. 2014. Use of milk proteins for encapsulation of food ingredients. In Microencapsulation in the Food Industry. Elsevier BV: Amsterdam, The Netherlands. 211-226.

Amezquita LEG, Chanes JW, Balderas FTV, Aquirre DB. 2016. Freeze-drying: The 
Basic Process. Encyclopedia of Food and Health. 104-109.

Basholli-Salihu M, Mueller M, Salar-Behzadi S, Unger FM, Viernstein H. 2014. Effect of lyoprotectants on b-glucosidase activity and viability of Bifidobacterium infantis after freeze-drying and storage in milk and low pH juices. LWT - Food Science and Technology 57:276-282.

Castro-Cislaghi FPD., Silva CDRE, FritzenFreire CB, Lorenz JG, Sant'Ánna ES. 2012. Bifidobacterium Bb-12 microencapsulated by spray drying with whey: Survival under simulated gastrointestinal conditions, tolerance to $\mathrm{NaCl}$, and viability during storage. Journal of Food Engineering 113: 186-193.

Doherty S, Gee V, Ross RP, Stanton C, Fitzgerald G, Brodkorb A. 2011. Development and characterisation of whey protein micro-beads as potential matrices for probiotic protection. Food Hydrocolloids 25: 1604-1617.

Dolly P, Anishaparvin A, Joseph GS, Anandharamakrishnan C. 2011. Microencapsulation of Lactobacillus plantarum (mtcc 5422) by spray-freezedrying method and evaluation of survival in simulated gastrointestinal conditions. Journal of Microencapsulation 28: 568574.

Gómez-Mascaraque LG, Morfin RC, PérezMasiá R, Sánchez G, López-Rubio A. 2016. Optimization of electrospraying conditions for the microencapsulation of probiotics and evaluation of their resistance during storage and in-vitro digestion. LWT-Food Science and Technology 69: 438-446.

Hamsah, Widanarni, Alimuddin, Yuhana M, Junior M Z. 2017. Bacterial population, activity of enzymes and growth rate of Pacific white shrimp larvae administered Pseudoalteromonas piscicida and mannanoligosaccharide through bioencapsulation of Artemia sp. Research Journal of Microbiology 12: 128-136.

Hamsah, Widanarni, Alimuddin, Yuhana M, Junior MZ, Hidayatullah D. 2019. Immune response and resistance of Pacific white shrimp larvae administered probiotic, prebiotic, and symbiotic through the bio- encapsulation of Artemia sp. Aquaculture International 27: 567-580.

Krolcyzk JB, Solowiej BG, Turak, EJ. 2016. Use of Whey and Whey Preparations in the Food Industry- a review. Polish Journal of Food and Nutrition Sciences 66(3): 157165.

Martin MJ, Lara-Villoslada F, Ruiz MA, Morales. 2015. Microencapsulation of bacteria: A review of different technologies and their impact on the probiotic effects. Innovative Food Science and Emerging Technologies 27: 15-25.

Maqsood S, Al-Dowaila A, Mudgil P, Kamal H, Jobe B, Hassan HM. 2019. In-dept characterization of protein and lipid fractions from camel and cow milk, their functionality, antioxidant and antihypertensive properties upon simulated gastro-intestinal digestion. Food Chemistry 279: 328-338.

McClements DJ. 2012. Requirements for food ingredient and nutraceutical delivery systems. In Encapsulation Technologies and Delivery Systems for Food Ingredients and Nutraceuticals. Woodhead Publishing: Sawston, UK 3-18.

Monnard PA, Oberholzer T, Luisi P. 1997. Entrapment of nucleic acids in liposomes. Biochimica et Biophysica Acta (BBA) Biomembranes 1329: 39-50.

Mortazavian A, Razavi SH, Ehsani MR, Sohrabvandi S. 2007. Principles and methods of microencapsulation of probiotic microorganisms. Iranian Journal of Biotechnology 5: 1-18.

Mulvihill DM, Donovan M. 1987. Whey proteins and their thermal denaturation-A review. Irish Journal of Food Science and Technology 11:43-75.

Nayak S K. 2010. Probiotics and immunity: A Fish Perspective. Fish and Shellfish Immunology 29: 2-14.

Nimrat S, Suksawat S, Boonthai T, Vuthiphandchai V. 2012. Potential Bacillus probiotics enhance bacterial numbers, water quality and growth during early development of white shrimp (Litopenaeus vannamei). Veterinary Microbiology 159: 443-450. 
Pech-Canul ADLC, Ortega D, Garcia-Triana A, Gonzalez-Silva N, Solis-Ovedo RL. 2020. A brief review of edible coating materials for the microencapsulation of probiotics. Coatings 10: 197.

Richards GP, Watson MA, Needleman DS, Uknalis J, Boyd EF, Fay JP. 2017. Mechanisms for Pseudoalteromonas piscicida-induced killing of vibrios and other bacterial pathogens. Applied and Environmental Microbiology 83 (11): 17517.

Santivarangkna C, Kulozik U, Foerst P. 2007. Alternative drying processes for the industrial preservation of lactic acid starter cultures. Biotechnology Progress 23: 302315.

Semyonov D, Ramon O, Kaplun Z, LevinBrener L, Gurevich N, Shimoni E. 2010. Microencap-sulation of Lactobacillus paracasei by spray freeze drying. Food Research International 43: 193-202.

Shori AB. 2017. Microencapsulation improved probiotics survival during gastric transit. HAYATI Journal of Biosciences 24: 1-5.

Wang YC, Yu RC, Chou CC. 2004. Viability of lactic acid bacteria and Bifidobacteria in fermented soymilk after drying, subsequent rehydration and storage. International Journal of Food Microbiology 93: 209217.

Widanarni, Tepu I, Sukenda, Setiawati M. 2009. Selection of probiotic bacteria for vibriosis biocontrol in tiger shrimp larvae, Penaeus monodon uses a shared culture method. Jurnal Riset Akuakultur 4: 95-105.

Zokaeifar H, Babaei N, Saad CR, Kamarudin MS, Sijam K, Balcazar JL. 2014. Administration of Bacillus subtilis strains in the rearing water enhances the water quality, growth performance, immune response, and resistance against Vibrio harveyi infection in juvenile white shrimp, Litopenaeus vannamei. Fish and Shellfish Immunology 36: 68-74.

Zou Q, Liu X, Zhao J, Tian F, Zhang H, Zhang H, Chen W. 2012. Microencapsulation of Bifidobacterium bifidum F-35 in Whey Protein-Based Microcapsules by Transglutaminase-Induced Gelation. Journal of Food Science 77(5): 270. 